\title{
Remembering bodies: picturing the body in Hungarian cinema after the fall of communism
}

\author{
Teréz Vincze \\ Department of Film Studies, Eötvös Loránd University, Budapest, Hungary
}

\begin{abstract}
One of the most interesting features of contemporary Hungarian cinema is the frequent use of bodies and corpses as central tropes in films. The directors of the so-called Young Hungarian Cinema of the 2000s often build their stories around bodies in order to discuss various psychological, social and historical problems. The great number of such films seems to indicate that this phenomenon is part of an overall trend in Hungarian films that, in many cases, has a direct connection to the representation of historical memory and the depiction of post-socialist identity formation. In this article, I examine two films, István Szabó: A napfény íze/Sunshine (1999) and György Pálfi: Taxidermia (2005), that use the body as one of their main tools for dealing with the questions of historical memory and the depiction of socialist and post-socialist identity. The selection of these two films also provides an opportunity to detect the differences between the approach of two generations of filmmakers to the historicization of socialism and to the post-socialist condition.
\end{abstract}

\section{KEYWORDS}

Contemporary Hungarian cinema; post-communism; body; memory; István Szabó; Sunshine; György Pálfi; Taxidermia

\section{Introduction}

The Hungarian film Meteo, directed by András Monory Mész, was produced in 1989, the emblematic year of Eastern Europe's political transformation. This highly symbolic film, which gained cult status soon after its release in Hungary, takes place somewhere in Eastern Europe; the allegorical location is a worn-out factory district that is destined for demolition. The main characters live in the factory, so they will soon have to move out. One of the characters - aptly called Little Cloud - is a meteorologist who spends his time daydreaming, and he symbolizes a certain type of the prophetic and vulnerable Eastern European intellectual. ${ }^{1}$ Little Cloud has figured out the ultimate winning strategy at horseraces and with it his friend, Berlioz, hits the jackpot at the next derby. Meanwhile, Little Cloud loses his life in an accident. The planned demolition of the factory district is cancelled, although the inhabitants of the godforsaken land seem to be eager to escape. Berlioz takes the money and gets on a plane, while the corpse of Little Cloud is sent up into the clouds with the help of several meteorological balloons. One of the last images of 
the film captures Berlioz staring out of the plane's window to see the corpse of Little Cloud ascending towards the sky.

The story of Meteo - set in a place where a community on the verge of disintegration try to find (often illegal) ways to survive - not only symbolizes the general situation of Eastern Europe at the dawn of the political and social changes caused by the fall of state socialism, but also creates a telling bodily symbol. The unburied dead body of Little Cloud, that is, invokes the series of dead bodies that were exhumed, moved and reburied in many countries of the ex-socialist bloc at the time. According to Katherine Verdery, the transformation of the system reconfigured the structure of the world and the possible forms of existence in this world for citizens in ex-communist societies. The events of 1989 had an immediate effect on some basic conditions of everyday living that had been stable and tacitly accepted for decades. The epochal shift in the system meant not only the alteration of abstract ideas about morality and social relations but had a literal effect on reality, which was materialized in everyday actions (Verdery 1999, 33-34). In this situation, as a means of negotiation between abstract ideas and immediate reality, dead bodies played an important role.

Verdery adds that Hungarians were extremely active in moving dead bodies within Hungary and across borders both before and after the political changes of 1989. Reburials of historical personalities had become part of enacting collective memory in Hungary well before communist times. For example, a change of political climate was signalled at the end of the nineteenth century by the reburials of the leaders and martyrs of the 1848 Hungarian revolution (Rév 1995). During communist times, the rehabilitated show-trial victim László Rajk was reburied in 1956 (and again in 1989). The years around 1989 appear to have been the busiest period: the remains of composer Béla Bartók was brought home from the United States in 1988, and several emigrant liberal and conservative politicians of the early twentieth century were reburied between 1990 and 1993 (Verdery 1999, 14-16). Probably the most important, highly symbolic act of reburial took place in June 1989 when the martyrs of the 1956 revolution, among them prime minister, Imre Nagy, and several members of the revolutionary leadership, were ceremonially reburied in Budapest.

Traditionally, the bodies of political leaders can serve as symbols of political order, hence political transformation can also be symbolized through the manipulation of these bodies. As John Borneman argues in connection with the political systems of tyrannical authority, just as the symbolization of the leader's living body is often central to such systems, the public symbolization of his mode of death and the dead body can be central to the successor regime as well (Borneman 2004, 2). Also, the ruler's body and its public, ceremonial representation embodies power and authority, 'that is why political disputes so frequently resort to visual caricature, in which the body-image of the rulers is physically distorted; caricature deforms in order to ridicule the imposition of an embodied authority' (Connerton 1989, 90). As Connerton also notes, it is not a coincidence that the French Revolution, as an epochal event, brought drastic changes to the public representation of common bodies, and also involved the severing of heads (Connerton 1989, 4).

It is not surprising then that the filmic representations of political change also animate deformed and dead bodies. One of the most interesting features of Hungarian cinema of the new millennium seems to be the reappearance of significant corpses on the screen in great numbers. The directors of the younger generation often use corpses and bodies as 
their central symbols in order to discuss various psychological, social and historical phenomena. The great number of contemporary Hungarian films that symbolically deploy bodies seems to prove that this phenomenon is an integral part of an overall trend that, in many cases, has a direct connection to the representation of memory (historical and/or personal) and the depiction of post-socialist identity formation (Strausz 2011b).

In this article, I intend to examine two films, István Szabó's A napfény ize/Sunshine (1999) and György Pálfi's Taxidermia (2005), which use the body as one of their main tools for dealing with topics such as historical trauma and progress, memory and forgetting, and the depiction of socialist and post-socialist identity. The former film was directed by a member of the older generation whose career started during, and has covered the decades of, the communist regime, while the latter was made by a younger director who, although he spent his early years in the socialist system, became an adult after the fall of communism. Hence, the selection of these two films provides an opportunity to detect some generational differences between approaches to the historicization of socialism and to the post-socialist situation.

\section{The return of bodies}

The members of the so-called 'Young Hungarian Cinema', the new generation of directors in their thirties who started to obtain international recognition at the beginning of the 2000s, were obviously interested in the body as an expression of varied historical and social phenomena. Hungarian cinema of the last 15 years is full of expressly body-oriented films, and many of them represent bodies in new and intriguing ways. Many Hungarian film critics have argued that contemporary films revolving around the body form a significant trend in Hungarian cinema (Király 2015; Strausz 2011b; Gelencsér 2014; Kalmár 2013b).

In Adrienn Pál (by Ágnes Kocsis, 2010) and Johanna (by Kornél Mundruczó, 2005), female bodies play a crucial role, and as Király argues, in these films, the 'body becomes a surface, a screen onto which varied cultural discourses (...) can be easily projected' (Király 2015, 205). Body-centred cultural and iconographic readings are also pertinent in relation to Kontroll (by Nimród Antall, 2003), a film dealing with the (Eastern European) male identity crisis (Kalmár 2013a), and Fehér tenyér/White Palm (by Szabolcs Hajdu, 2005), which tells the story of an athlete who was brought up and trained in communist Hungary but, upon moving to Canada to work as a trainer, has to overcome his bodily and cultural reflexes to avoid being cast in the role of the (post-)socialist Other.

The significance of dead bodies in transitional societies, mentioned at the beginning of this essay, has been mirrored in Hungarian cinema during the last several years as dead bodies strangely started to come to prominence in films that regularly led their viewers into the mortuary by creating a certain subgenre of pathology. Beside the regular tours to the mortuary by the heroine of Adrienn Pál who works as a nurse on the terminal ward, the main hero of A nyomozó/The Investigator (by Attila Gigor, 2008) is himself a pathologist and a substantial amount of the story takes place in the mortuary among dead bodies, meanwhile the ambulance men of Isteni müszak/Heavenly Shift (by Márk Bodzsár, 2013) deal in dead bodies in a story that takes place in 1992, during the Croatian war of independence. 
The examples above strengthen the point that a body-oriented reading of contemporary Hungarian film culture does not simply overemphasize the trivial fact that each and every film in any era represents bodies. I also believe that many of the above-mentioned films by young Hungarian directors were able to perform successfully on the international festival circuit because their 'body language' is compatible with current international trends - they are able to communicate globally through the symbolic use of the body and through the carnal language of the bodily senses (Kalmár 2013b, 203-204; Lelkes 2013). As several scholars have already argued, there is a 'metagenre' of 'corporeal cinema' in Europe, and some of them positioned Christian Puiu's The Death of Mr. Lazarescu at the centre of the genre. 'Corporeal cinema', proposes Anikó Imre, 'consists of grim allegories that are preoccupied with "Eastern Europe's recent historical convulsions," including Béla Tarr's, Alexander Sokurov's, and Emir Kusturica's films' (Imre 2009, 215). It also seems that Hungarian directors of the older generation who have been well-received internationally - such as István Szabó, Béla Tarr or Márta Mészáros - all depend heavily on accentuated representations of the body. Hence, one of the interesting questions is whether there is any significant difference between the older and younger generation of film directors concerning the representation of the memory of the socialist past and, to further narrow the question, how this difference can be detected through their use and representation of the body. Sunshine by István Szabó and Taxidermia by György Pálfi provide material for a comparative analysis in this regard.

\section{Two types of embodied memories}

Szabó's epic follows the story of the Jewish Sonnenschein family over three generations and represents different strategies of assimilation pursued by its heroes. Ralph Fiennes plays the father (Ignátz), son (Ádám) and grandson (Iván) of the family. Ignátz's story begins the film with flashbacks about his father and grandfather who invented a formula for a herbal tonic called 'Sunshine' which the family fortune was founded on. His father was a successful businessman and Ignátz chose to become a lawyer in the Austro-Hungarian empire. He is a devoted supporter of the regime and admirer of the emperor. In order to advance his career, the family name is changed to Sors to sound more Hungarian. After the First World War, Ádám converts to Catholicism to join an officers' club and participate at the Berlin Olympics where he wins a gold medal for fencing. However, being a Hungarian army officer and an Olympic medallist does not save him from being murdered by anti-Semitic guards in a labour camp during the Second World War. Ádám's son Iván, who witnessed his father's death, becomes a police officer under the communist regime after the war. He is confronted by the cruelty and injustices of the system and in 1956 participates in the revolution against the regime and is sentenced to prison. After three years in prison he returns home and clears out his grandmother's home, destroying the remnants of the past. In a scene evoking the destruction of Rosebud in Citizen Kane, we watch as the secret recipe of 'Sunshine' is lost forever. Finally, Iván changes back his name to Sonneschein. The plot ends at the beginning of the 1960s but the narration by Iván states that he is telling this story after the fall of the communist system.

Taxidermia consists of three parts, each representing a different period of recent Hungarian history. The first part, although not clearly specified, most probably takes place during the Second World War, the second is about the socialist period, and the final part 
takes place in contemporary, post-socialist Hungary. Like Sunshine, it is a story of three consecutive generations of men. What makes questionable whether the film can be called a family story or not is the fact that in each episode it is strongly suggested that the sons were born as illegitimate children. At the beginning, we follow the story of an officer, his family and his servant (Morozsgoványi) at a military post-far away from operations. The servant spends most of his time either sexually stimulating his own body, or (day)dreaming about sexual intercourse; he is eventually murdered by the officer who discovers that the orderly finally made love to his wife. In the second part, the (illegitimate) child of the officer is a national champion of the overly disgusting sport of speed eating that consists of bizarre training practices and the competitive consumption of inedible substances such as textiles. The film depicts the formative years of the hero as a young speed eater, his career as a competitive athlete in an over-politicized regime, and his marriage to the female national champion of the same sport. The final episode tells the story of the son of the speed eater, a taxidermist. He takes care of his father whose immense body, the consequence of his career, makes him unable to care for himself. After his father's death, the son stuffs the body of his father and commits suicide by the help of a 'taxidermy machine' that not only kills but also stuffs the body of the taxidermist. The film concludes as the stuffed dead bodies of father and son are exhibited in a modern art gallery.

There are obvious similarities between the two films. Both of them tell the story of multiple generations of male protagonists and represent several consecutive periods of Hungarian history, and include reflections on the communist era. Both films thematically problematize the concept of historical progression - Sunshine through the recurring motif of incest, Taxidermia through the genealogy of bastardly offspring. And most importantly for my argument: both films depend heavily on certain concepts of materiality and the body as sites of meaning production.

The sophisticated language of touches and gestures, and bodily sensibilities in general, has always played an important role in István Szabó's films. One of the more prominent examples can be found in his film Szembesités/Taking Sides (2001) about the renowned German conductor Wilhelm Furtwangler. The whole film can be read as an extended interpretation of a small, almost invisible, unconscious gesture present on archival footage capturing the moment of Furtwangler's handshake with Goebbels after a concert he conducted. The little movement repeated in slow motion at the end of the film as Furtwangler, with an almost motoric gesture, changes a handkerchief from one hand to another, seems to be an unconscious answer of muscles, the protest of the body against the institutional force that made the handshake unavoidable (K. Horváth 2003, 67). A similar moment can be found in Sunshine when Ignátz Sors meets the emperor Franz-Joseph. As the narrator states: 'this was probably the most important moment of my grandfather's life'. And the moment is accentuated by the Kaiser touching the arm of Ignátz, and several moments later Ignátz acknowledges the bodily experience by repeating the gesture towards his own arm.

It is the extensive use of bodily sensibilities in the film that could have led some British writers to criticize the film for over-emphasizing sexuality (Cunningham 2014, 105). As Imre notes in connection with the affective qualities of Szabó's films: 'Perhaps the bestknown instances of male artist characters whose appearance and subjectivities "open in a variety of ways onto the domain of femininity" and foreground "castration, alterity and specularity," [...] are the protagonists of István Szabó's "Central European trilogy” [...], 
all played by Klaus Maria Brandauer' (Imre 2009, 173). I believe that what is identified here as 'femininity' and 'specularity' is closely connected to the general bodily sensibilities present in Szabó's cinema, Sunshine included.

The question of the body is central to many of Szabó's films and this provides the opportunity for researchers to read his whole oeuvre from the perspective of bodily concepts (Dragon 2006). In the following analysis, however, I am particularly interested in the difference between his and György Pálfi's concept of the cinematic body, and its use in the context of historical memory.

At the beginning of Sunshine, while the credits roll, the background is filled with clouds; after the credits end and the first image shows a landscape, clouds are still visible over a silhouette of hills. A young boy appears in the picture and approaches us while the narrator announces him as his great-grandfather, the founder of the Sonnenschein (Sunshine) dynasty. At the beginning of Sunshine, the protagonist and the story descend from the clouds - just like sunshine reaches earth after traveling through clouds. At the end of the film - after the son of the third generation of the family had changed his name back to Sonnenschein - we (together with the camera) exit the world of the story by ascending towards the sky and leaving our hero behind. Thanks to the use of this stylistic device that frames the story, and to the word 'sunshine' that is present at the beginning (the title 'Sunshine' is written on the image of clouds in the opening credits) and at the end [Iván changes back his name to Sonnenschein (sunshine)], and connotes immateriality, it is the eternal aspect and moral of the story that is stressed here. The narration by Iván frames the film and makes it possible to interpret it as a recollection and also as a testimony since the narrator was the witness of many of the events depicted in the film.

It is worth comparing the above-mentioned scenes to the beginning and end of Taxidermia. A voice-over also frames this film. This narrator is not an integral part of the story being told, yet, without him - as he reassures us - maybe no one would know about it. An art connoisseur and curator, he has found two artefacts (body sculptures created by a taxidermist out of the body of his own father and himself), and thanks to them the whole story is worth being told now. As he says: 'Maybe this is only important because this is the end of something. And if something comes to an end, then its beginning will also be important.' The narrator is not necessarily reliable; at least he says things at the end of the film that are not in accordance with what we have seen. In his opening speech, at the exhibition of the body sculptures, he mentions witnessing the moment when the taxidermy machine sprung into action and mutilated the body of the taxidermist. However, not long before, we clearly saw that he arrived in the basement, where he found the stuffed corpses, sometime after the whole process was finished. This obvious incongruity can be interpreted as a commentary by the director about the problems concerning the recollection of history.

One of the basic differences between the concept of history as presented in Szabó's and Pálfi's films can be described as the opposition of organic continuity versus fragmented discontinuity. Szabó stresses the concept of continuity in many ways, but in this article I will concentrate only on those aspects that are connected to the body. As Catherine Portuges notes: '...Sunshine foregrounds the residual intergenerational effects of trauma by using the same actor (Ralph Fiennes) in the role of witnessing presence through four successive generations of Sonnenscheins' (Portuges 2012,111). Szabó often uses this literal bodily connection between characters even across multiple films. For example, one of his 
trademarks is the use of the same actor throughout a series of films. ${ }^{2}$ Although these characters have different names in each film, the impression remains that they embody the same person (Dragon 2003, 42).

Another notable aspect of continuity in Szabó's films is connected to the representation of kinship and genealogy. National identity and history in the film is represented through kinship structures and the succession of blood-related generations. What is interesting in the case of Szabó's generational connections is his inclination towards the literal and metaphoric use of the incest motif. Zoltán Dragon in his analysis of Sunshine reads all of the male-female relationships of the film as actually or symbolically incestuous. The married Vali and Ignátz in the first generation are cousins, Ádám of the second generation has an affair with his sister in law, and in the communist episode the love of Iván and his female comrade can be interpreted as a love story between the children of the party, between a brother in arms and a sister in arms (Dragon 2000, 92-93). Dragon also points out the many examples of symbolic brother-sister love stories in Szabó's earlier films. ${ }^{3}$

In a way, the motif of incest stresses closeness, relations and blood ties in the progression of history, but at the same time, 'dangerously' close family ties also refer to the fractures and dislocations of historical time. But ultimately it is the temporal and generational continuity that is accentuated and reconfirmed by multiple motifs during the film. A watch and a black notebook with the recipe of the Sunshine liquor embody the continuity of the family line and reappear in each generation's story. Similarly, the motif of placing the new-born child on the mother's body is repeatedly shown, and again creates a bodyrelated expression of continuity.

Quite unlike Szabó's Sunshine, Pálfi in Taxidermia stresses the discontinuity of history. As Steven Shaviro pointed out, 'Taxidermia does not tell an actual story so much as dramatize and explore a discontinuous series of attractions and repulsions among grotesquely deformed bodies' (Shaviro 2012, 31). The historical periods depicted do not seem to represent historical development or connection. Although the three generations of men are supposed to embody continuity, in each case, it is suggested that their offspring are illegitimate children; fathers and sons in this (hi)story are never blood relatives. The sense of fragmentation is stressed further by the absurd differences between the bodies of father and child. The undernourished, hare-lipped Morozsgoványi could not be more different from the gigantic speed eater Kálmán. And again, Lajoska the ghostly, anorexic taxidermist of the third episode, who by profession removes the contents of bodies, is the opposite of his father whose body is a bottomless container for anything barely eatable. The three men and the three bodies, in a way, represent degeneration. The illegitimate status of each child emphasizes the fractures of history, meanwhile the gradual desexualization of their bodies - from sex-obsessed Morozsgoványi through Kálmán cuckolded by his wife to Lajoska who is unable to initiate relationships with women - signals the progress towards the sad end of a family history staged in the sterile space of a modern museum.

The discontinuity is further stressed stylistically at the switching points between historical periods and generations. '[T] he passage of time [is] elided and replaced by a camera movement through space. [...] History does not progress, it merely reconfigures, trading one way of breaking down the male body for another' (Shaviro 2012, 32). Hence, history is represented as the unstoppable replacement of one body with another, and the wheel of history is kept in motion by the constantly changing bodies. At the beginning of the film, this dynamic is clearly powered by the vivid energy of carnal desire embodied by the sex- 
obsessed Morozsgoványi. But the shift from this rather organic metaphor of historical forces towards a more abstract signification of change starts already in the first part. The discontinuity or the lack of organic interrelations in cosmic and historical structures is stressed by the use of indexical visual tropes instead of psychological motivation. One of the finest examples of this technique can be found in the first episode when a revolving wooden tub becomes the allegory of time, change and life as the director places the widest possible variety of bodies and flesh into it, including living human bodies, the intestines of butchered animals and a corpse.

In accordance with the aspiration to create abstraction, taxidermy and mechanical, inorganic machines become the film's central trope that culminates in the scene involving the taxidermy machine. This complex trope brings together the main themes of the film: cinema, body, machine, history. The taxidermy machine quite directly evokes the traditional material apparatus of film (intestines are moving around between spinning disks just as celluloid moves inside a camera or a projector). Film art itself is literally compared to an autopsy in this scene. This trope suggests that Taxidermia itself can be interpreted as the autopsy machine of Pálfi. His film chops up history in order to reveal its hidden parts, and the process of the autopsy is more important than creating a meaningful, wellformed, though at the same time obscuring, surface as a display for historical memory.

All of this is in stark contrast to the way Szabó uses the body. In Sunshine, the visual representations of the body are configured as less mechanical, more humanistic, psychology-driven metaphors. For example, one of the central body metaphors of the film is the relation between the body of Ádám (the Olympic champion fencer who died in a concentration camp) and his son, Iván (who became a member of the communist state security forces). The father dies encased in frozen water, while the son - who witnessed his father's death -is later shown covered in water in the shower while his superior attacks him and calls him a traitor (Figures 1 and 2).

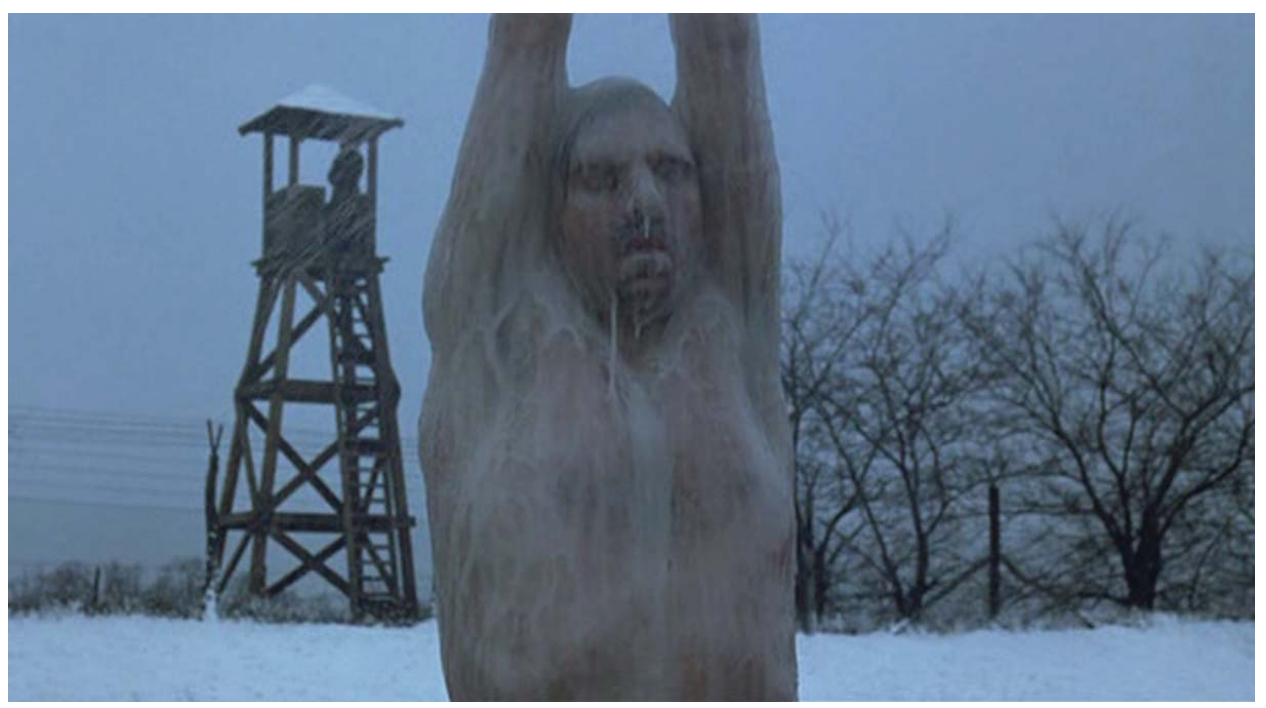

Figure 1. Father and son: Ádám encased in frozen water. 


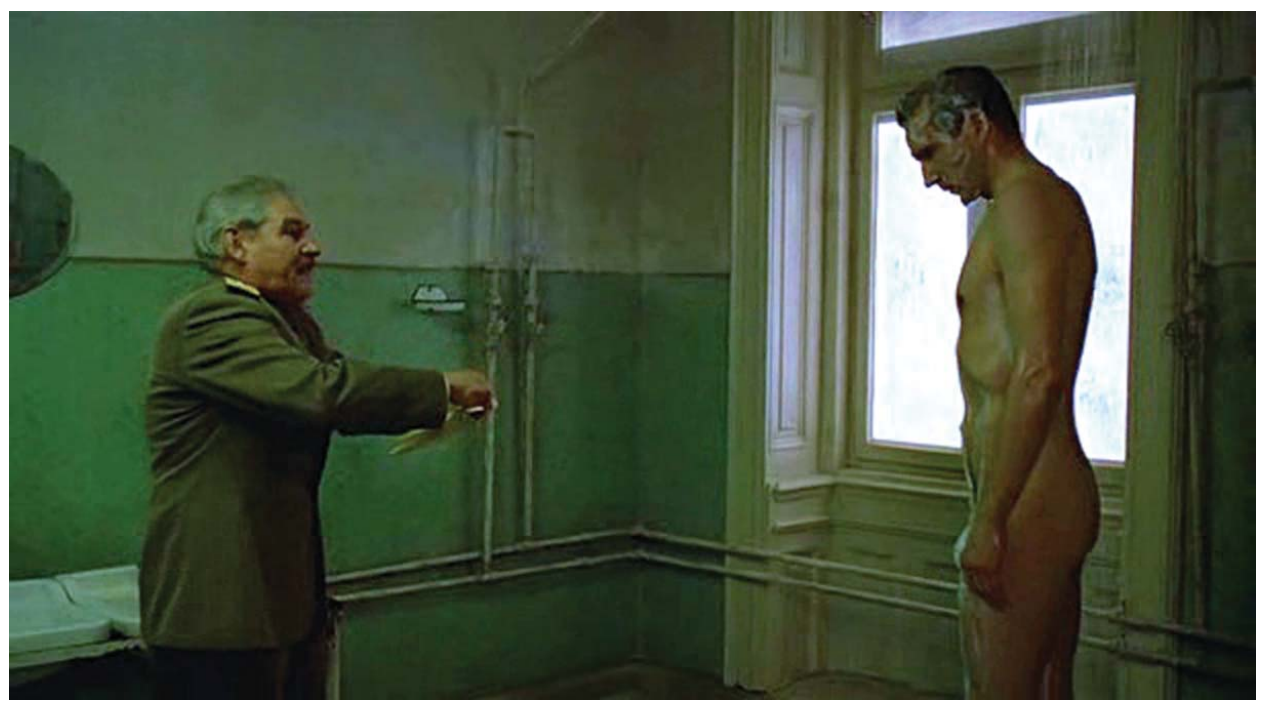

Figure 2. Iván humiliated by his supervisor.

Catherine Portuges reads the scene of Ádám's death as 'a simulacrum of the Holocaust' and Iván as 'the witnessing presence' (Portuges 2012, 111). Considering Szabó's film as an act of memory work, it is important to note that this witness is the narrator of the family's history in the film. He was the witness of trauma and traumatized by the event. Although Freud, and also Lacan, conceptualized trauma in psychological terms as a consequence of an event that leaves long-lasting effects on the psychic life of the subject (Freud 1963), the word 'trauma' is etymologically linked to the Greek word 'wound' and 'damage', derived from the verb 'to pierce', and means an injury to the body. Iván's body in the shower scene experiences water under different, less fatal but also humiliating circumstances. Through his bodily experience, the scene emphasizes the 'transgenerational transmission of trauma' (Portuges 2012, 101), hence the trope of the body is propelled by psychological motivation.

Through the motifs of kinship and the body, the interconnectedness of the generations of the Sors/Sonnenschein family is heavily stressed. And thanks to the positioning of the narrator as a witnessing family member and also a story teller, the agent of remembering, the natural, generational connections that constitute family and on a different level nation, and history as a tale of these connections, has a certain element of transcendence. This is expressed at the beginning and end of the film through the motif of clouds and the ascension towards the sky. History is represented as a well-formed narrative where choices and decisions made by individuals organically connect the generations and lead them towards a predestined fate or ending that, literally, resides above them. This dynamic is aptly represented by the Hungarian name the family choses ('Sors' means fate in Hungarian), and the fact that the last generation changes it back to the original, ethereal 'Sunshine'. This gesture together with the last camera movement towards the sky, in a way, expresses the restoration of the cosmic order. And as John Cunningham notes, the end of the story has an optimistic tone - 'the sun(shine) is beautifully bright and Iván strides through the street with confidence and determination as if he knows exactly where he is heading. [...] 
Just a few paces behind him walks the director making a brief appearance...' (Cunningham 2014, 105).

Even authorial bodies are treated antithetically in these films. In Taxidermia Lajos Parti-Nagy - the author of the short stories the film is based on - is seen as a dead body laid out in the wooden tub that represents the eternal repetition of life and death in the first part. It is almost too obvious to read these two moments as the epitome of the difference between authorial roles in an organic and a mechanic concept of historical memory. In the case of Szabó, the author is present in the diegetic world of his story representing a living witness of history. This presence, in the traditional sense of 'auteurism', validates the story; the artist stands as a guarantor for artistic and historical truth. In Pálfi's film, the dead body of the author symbolizes the loss of authority over meaning and truth in the Barthesian sense (Barthes 1967). The author has lost the capacity to create organic connections out of the chaos of history; he has become a simple link in the chain of historical events.

The bodily and material practices that frame Taxidermia are strikingly different from the above-mentioned ethereal gestures in Szabó's film. While the film starts with the godlike sound of the invisible narrator who states that without him the whole story would not exist at all, the first fragmented images show the body of the military officer's servant who stimulates himself by the flame of a candle. The film's last shot depicts the stuffed torso of the taxidermist, while the camera zooms into his navel and further inside his body, ending in darkness. Both the beginning and the end of the film stress the literal, non-transcendental presence of the material body.

This strategy seems to be closely connected to the representation of socialism. As László Strausz puts it, in the second part of the film, Pálfi focuses 'on the changes caused by socialism in people's relation to the material object-world: the ideology of collective property and the lack of private property finds itself expressed in the grotesque distortions of devouring' (Strausz 2011a). The compulsion for stuffing themselves makes these bodies symbolically and literally heavy. And Kálmán Balatoni's huge and unmoveable body as the memento of socialism also has a prevailing presence in the post-socialist episode of the film. It is positioned as a historical ballast that keeps the son under control, and for whom the new, capitalist culture of consumption simply means the burden of buying extreme amounts of food in order to keep alive this frightening remnant of the past. The heavy monsters of the socialist past gobble up the future.

\section{Body sculptures}

Two further aspects of the representation of the body and history in the two films are worthy of comparison: the representation of sport, and the appearance of the body as statue or sculpture. As regards the former, Sunshine portrays a bourgeois, individualist concept of sport in association with the Coubertin Olympic Games, which was a preserve of the wealthier classes (Riordan 1991, 10). In Sunshine, the inclusion of Ádám, the fencing champion, into the Hungarian Olympic team symbolizes his individual effort to assimilate. The brutality and cruelty of his death in the labour camp is further amplified by the fact that it is the once victorious sportsman's body that is made immobile, frozen to death. On the other hand, Taxidermia reflects on the state-directed, utilitarian, public policy-oriented Soviet model of sport that considered it first and foremost as a political tool. The 
Soviet Union joined the Olympic Movement in 1951, and the Olympic Games become another battlefield of the Cold War. It was not only individuals and nations who fought for Olympic medals, but also representatives of the Communist ideology against the Capitalist. Hungary had its fair share of this battle. Out of the nine summer Olympic Games in which communist Hungary participated, in eight cases, its delegation ended up among the best six countries on the medal chart. Sport in Hungary, just like in other communist countries, was closely related to state power and control. In these countries, many of the most important sport clubs were operated by the (secret) police or the armed forces (Riordan 1991, 2). This is one of the features that makes communist sport appropriate for Pálfi to use as an allegory of communist Hungary. In Taxidermia, as can be read on their shirts, the speed eaters are members of Honvéd (the sport club of the Hungarian armed forces). Furthermore, the surreal and inhumane coaching of speed-eaters from their early childhood in the film mirrors the practices of Socialist countries during the Cold War. In a system that claimed to be based on equality - which meant equal poverty for most - a sports career was one of the very few accepted methods to gain a better life, recognition and relative freedom. In order to gain these advantages, sports men and women let the state control their body, all too often by illegal drugs and drastic physical means. The deformed bodies of speed-eaters in Taxidermia also stand for the many socialist athletes crippled by doping practices. And the presence of the shapeless, unfit body of the exsportsman Kálmán Balatoni in the last episode embodies the experience of the members of the post-socialist community, who find that old practices of survival do not function anymore under capitalist circumstances.

Parallel with this concern with the sporting body lies the significance of statues and sculptures in post-socialist identity formation. One of the earliest visible signs of regime change in 1989 was the disappearance of statues from public spaces, indicating the fall from favour of certain historical personalities. In Hungary, the phenomenon even brought to life a very special 'lieux de mémiore' (Nora 1989), the Statue Park Museum, where the sculptures of fallen idols of the communist system were collected and displayed, and which 'discursively establishe[d] borders that separate post-communist Hungary from the forty-year experience of communism' (James 2005: 32). Although the moving and destroying of statues is not exclusive to post-socialist transitions, there are two features that characterize post-socialist practice specifically: the immense number of statues removed, and the fact that the 'statues have been treated rather like actual dead bodies, their empty pedestals becoming places of pilgrimage or otherwise manifesting religious and magical resonance' (Verdery 1999, 12). Both Szabó and Pálfi represent historical memory through bodies as statues in a more or less direct manner. Szabó's strategy is the less direct one: one of Sunshine's central bodies, the corpse of Ádám frozen into ice, can be read as a statue commemorating the Holocaust. As Cunningham mentions, Hungarian right wing critics denounced the representation of Ádám's death because it resembled the crucifixion of Jesus Christ (Cunningham 2014, 100). This observation underlines the possibility of interpreting Ádám's body as a statue of great historical significance. Taxidermia, on the other hand, directly connects the representation of the body to the statue and sculpture. The final scenes of the film show the morbid body sculptures of Kálmán and Lajos positioned in the almost anatomical, sterile interior of an art gallery surrounded by an audience whose members seem to be lifeless puppets themselves. The eternally frozen bodies of the two men signal the end of a family's history (Figures 3 and 4). 


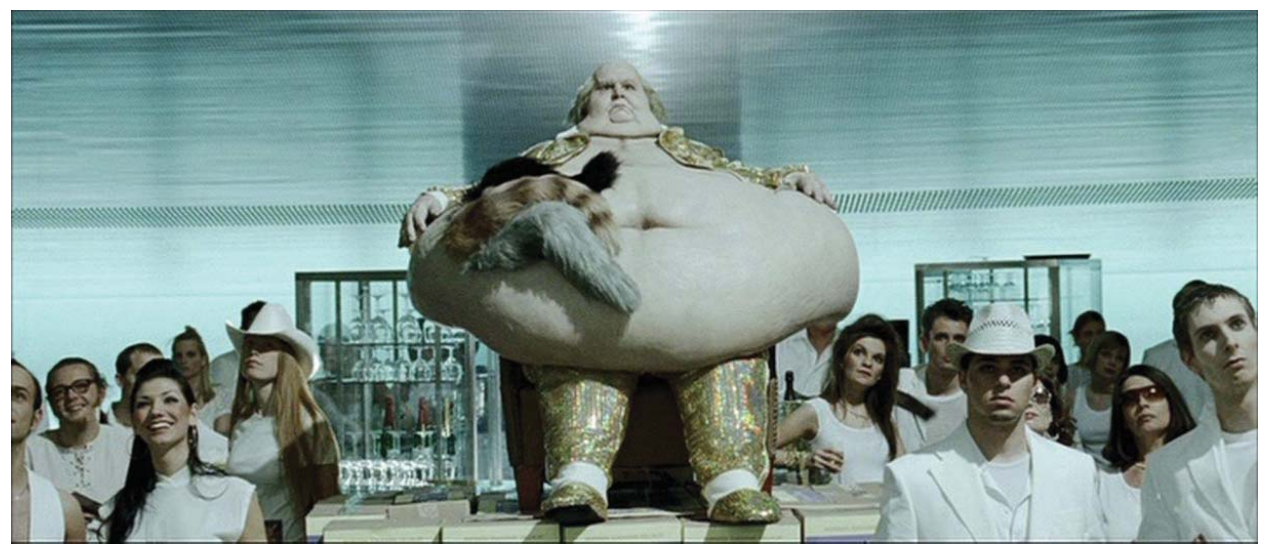

Figure 3. Father and son: the stuffed body sculpture of the father.

\section{Conclusions}

The films of Szabó and Pálfi discussed above can be interpreted as takes on the bodily politics of cinematic remembering. The haunting presence of many significant bodies on the screen is open to different interpretations. Should they be read as embodied versions of the famous ghost, the one that Karl Marx identified 150 years ago as the 'spectre of Communism'? Or should these bodies and corpses be interpreted as voodoo dolls that help us to get rid of the evil spirits of the past? In Verdery's opinion 'dead bodies can serve as loci for struggling over new meanings' in many spheres of society (Verdery 1999, 36). I believe that the two films testify that in turbulent historical periods, such as the post-socialist era, many types of bodies, dead or alive, can serve such a purpose.

In Eastern Europe [...] rewriting history has been perhaps unusually necessary because of powerful pressures to create political identities based expressly on rejecting the immediate past. [...] The revisionist histories that corpses and bones embodied were therefore central to dramatizing the end of Communist Party rule. (Verdery 1999, 52)

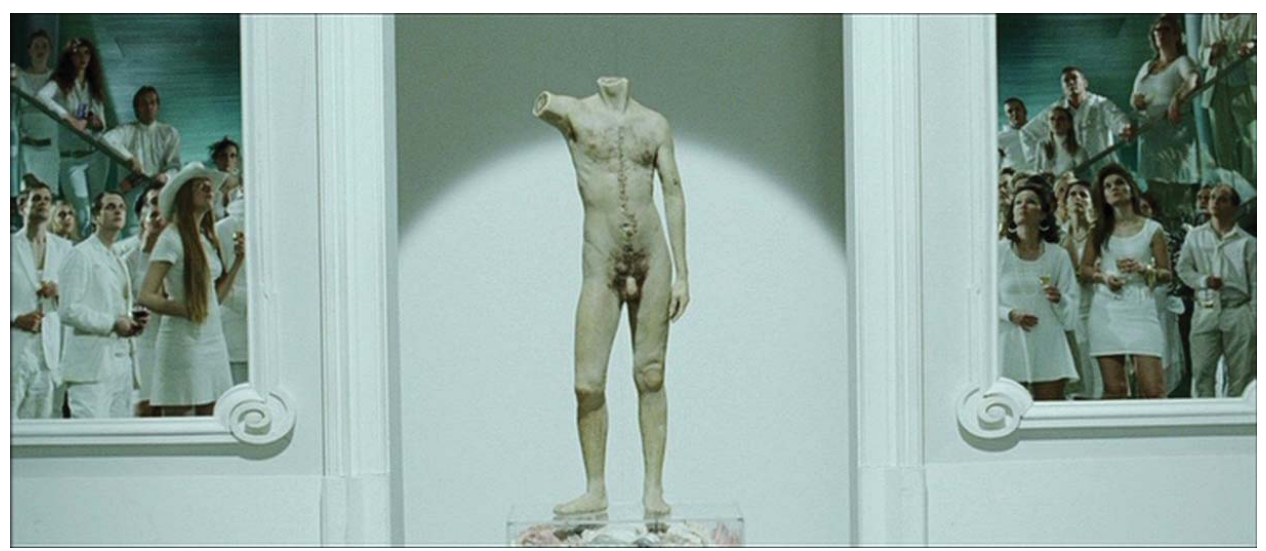

Figure 4. The stuffed body sculpture of the son. 
Both Szabó and Pálfi choose to remember and tell the story of the past, and through this gesture suggest that a meaningful present cannot be built on rejection and forgetting. However, the motif of rejection is very significant in both films. At the end of Sunshine, Iván destroys all of the material remnants of his family's past, and the film itself deletes the whole history of the Kádár regime by skipping three decades. Iván's voice-over states that the communist system has already ended. Pálfi in Taxidermia clearly denounces communism by representing it as disgusting, corrupt and having led to the complete destruction of their heroes and their descen$\operatorname{dant}(\mathrm{s})$.

The various bodies in Szabó's and Pálfi's films help to mediate between rejection and remembering. And - as László Strausz suggest in connection with Taxidermia's symbolism - this is also a strategy that helps fight against 'the tragic-heroic resistant nation myth' that 'diverts the attention away from individual responsibility and positions the entire community (the nation) as passive and suffering' (Strausz 2011a). Although in different ways, both Sunshine and Taxidermia use the body to corporealize history and remembering. By inscribing the traces of history directly on individual bodies, too, these films effectively address the individual bodies of the audience. Disgust, shudders and chills experienced by viewers while watching these bodies may enable them to sense both the corporeality of history and personal involvement that must be part of the collective historical memory.

\section{Notes}

1. Anikó Imre discusses Eastern European masculinities before and after the political change, and particularly examines the figure of 'the Eastern European Intellectual' or 'the artist' (used as almost coterminous names) in films of the 1980s and 1990s produced in the region. According to Imre, 'They are short on muscles but abundant in verbal expression. They are self-conscious, narcissistic, masochistic, often tragic and self-destructive, prophetic, and, above all, extremely vulnerable' (Imre 2009, 169). The character of Little Cloud is a variation on this intellectual/ artist who is short on muscles (in this case, he is short on words as well), a romantic and prophetic type, the epitome of vulnerability.

2. András Bálint is present in many of the early films [Álmodozások kora/The Age of Daydreaming (1965); Apa/Father (1966); Szerelmesfilm/Lovefilm (1970); etc.), and Klaus Maria Brandauer in the Central European trilogy [Mephisto (1981); Redl ezredes/Coloner Redl (1985); Hanussen (1988)].

3. The motif is present in The Age of Daydreaming, in Lovefilm, and in Bizalom/Confidence (1980) (Dragon 2000, 98-100).

\section{Disclosure statement}

No potential conflict of interest was reported by the author.

\section{Funding}

This work was supported by the János Bolyai Research Scholarship of the Hungarian Academy of Sciences, and the Hungarian Scientific Research Fund [project number NN 112700], [project number K 116708]. 


\section{Notes on contributor}

Teréz Vincze is an assistant professor of film theory and film history at the Department of Film Studies of Eötvös Loránd University, Budapest. Since 1999, she has been the editor of the Hungarian quarterly journal of film theory and film history, Metropolis. She is also a member of the editorial board of the Slovakian quarterly journal, Kino-Ikon. She has been teaching film studies at ELTE University since 2002, and received the $\mathrm{PhD}$ degree at the same university in Film Studies in 2009. Her articles about film and television history have been published in English, Italian, Czech and Slovak in edited books and in film journals. Her first book (Author in the Mirror: Auteurism and Self-Reflexivity in Cinema) was published in 2013 in Hungarian. Her current research interests include the role of the body and bodily sensations in the cinema, spatial aspects of media studies, gender representation in film and auteurism in East Asian cinema.

\section{References}

Barthes, Roland. 1967. ““The Death of the Author", Translated by Richard Howard.” Aspen 5-6. http://www.ubu.com/aspen/aspen5and6/threeEssays.html\#barthes

Borneman, John. 2004. "Introduction: Theorizing Regime Ends." In Death of the Father: An Anthropology of the End in Political Authority, edited by John Borneman, 1-31. New York: Berghahn Books.

Connerton, Paul. 1989. How Societies Remember. Cambridge: Cambridge University Press.

Cunningham, John. 2014. The Cinema of István Szabó. Visions of Europe. London: Wallflower Press.

Dragon, Zoltán. 2000. “Kép, funkció, struktúra. A nő Szabó István filmjeiben.” Metropolis 4: $88-100$.

Dragon, Zoltán. 2003. ““Fölragyog tisztán belső napom.” A spektrális test feltűnése Szabó István Mephistójában." Metropolis 3: 42-57.

Dragon, Zoltán. 2006. The Spectral Body. Aspects of the Cinematic Oeuvre of István Szabó. Newcastle Upon Tyne: Cambridge Scholars Press.

Freud, Sigmund. 1963. "General Theory of the Neuroses (1917).” In The Standard Edition of the Complete Psychological Works of Sigmund Freud. Volume XVI: Introductory Lectures on PsychoAnalysis, Part III, translated and edited by James Strachey, 243-463. London: The Hogarth Press.

Gelencsér, Gábor. 2014. “Testi mesék: Johanna, Taxidermia, Fehér tenyér.” In Az eredendo máshol: Magyar filmes szólamok, edited by G. Gelencsér, 302-307. Budapest: Gondolat.

Imre, Anikó. 2009. Identity Games. Globalization and the Transformation of Media Cultures in the New Europe. Cambridge, MA: The MIT Press.

James, Beverly A. 2005. Imagining Postcommunism: Visual Narratives of Hungary's 1956 Revolution. College Station, TX: Texas A\&M University Press.

K. Horváth, Zsolt. 2003 "Néhány bevilágított mozgókép. Egy archív felvétel értelemrögzítése a Szembesités történetképében.” Metropolis 3: 58-68.

Kalmár, György. 2013a. "Hitehagyott testek. A Kontroll és a kelet-európai testpolitika." Metropolis 3: 38-48.

Kalmár, György. 2013b. "What the Body Remembers. The Memories of Eastern-European Body Cinema: Pálfi György's Taxidermia.” In Loci Memoriae Hungaricae: The Theoretical Foundations of Hungarian "lieux de mémoire" Studies, edited by Miklós Takács, 196-206. Debrecen: Debrecen University Press.

Király, Hajnal. 2015. “The Alienated Body. Smell, Touch and Oculocentrism in Contemporary Hungarian Cinema." In The Cinema of Sensations, edited by Ágnes Pethö, 185-208. Newcastle Upon Tyne: Cambridge Scholars Publishing.

Lelkes, Ilka. 2013. “Érzéki képek. Haptikus jegyek a kortárs magyar filmben.” Metropolis 3: 64-71.

Nora, Pierre. 1989. "Between Memory and History: Les Lieux de Mémoires." Representations 26: 7-24. 
Portuges, Catherine. 2012. "Jewish Identities and Generational Perspectives." In A Companion to Eastern European Cinemas, edited by Anikó Imre, 101-24. Malden, MA: Wiley-Blackwell.

Rév, István. 1995. “Parallel Autopsies.” Representations 49: 15-39.

Riordan, James. 1991. Sport, Politics, and Communism. Manchester: Manchester University Press.

Shaviro, Steven. 2012. "Body Horror and Post-Socialist Cinema: György Pálfi's Taxidermia." In A Companion to Eastern European Cinemas, edited by Anikó Imre, 25-40. Oxford: Wiley-Blackwell.

Strausz, László. 2011a. “Archaeology of Flesh. History and Body-Memory in Taxidermia.” Jump Cut 53. Accessed 10 February 2015. http://www.ejumpcut.org/archive/jc53.2011/strauszTaxider $\mathrm{mia} /$.

Strausz, László. 2011b. "Vissza a múltba. Az emlékezés tematikája fiatal magyar rendezőknél." Metropolis 3: 20-28.

Verdery, Katherine. 1999. The Political Life of Dead Bodies. Reburial and Postsocialist Change. New York: Columbia University Press. 